\title{
Soybean Yields and Biomass Production of Winter Cover Crops in the Southwest of Paraná - Brazil
}

\author{
Amarildo Antônio Tessaro ${ }^{1}$, Mauricio Antônio Pereira ${ }^{2}$, Ademir Calegari ${ }^{3}$, Sideney Becker Onofre ${ }^{4} \&$ Ricardo \\ Ralisch $^{1}$ \\ ${ }^{1}$ Universidade Estadual de Londrina - UEL - Centro de Ciências Agrárias, Rodovia Celso Garcia Cid, PR 445 \\ Km 380, Campus Universitário, Londrina - PR, 86055-900, Brazil \\ ${ }^{2}$ Universidade Federal do Paraná - UFPR - Programa de Pós-Graduação em Ciência do Solo, Rua dos \\ Funcionários, 1540, Juvevê, Curitiba - PR, 80035-050, Curitiba, Brazil \\ ${ }^{3}$ Instituto Agronômico do Paraná - IAPAR - Rodovia Celso Garcia Cid, km 375 - 86047-902 - Londrina-PR, \\ Brazil \\ ${ }^{4}$ Programa de Pós-graduação em Tecnologia e Gestão da Inovação - PPGTI - Universidade Comunitária da \\ Região de Chapecó - UNOCHAPECÓ - Chapecó - Santa Catarina, Brazil \\ Correspondence: Sideney Becker Onofre, Programa de Pós-graduação em Tecnologia e Gestão da Inovação - \\ PPGTI - Universidade Comunitária da Região de Chapecó - UNOCHAPECÓ - Chapecó - Santa Catarina, Brazil. \\ E-mail: beckerside@unochapeco.edu.br
}

Received: July 21, 2019

doi:10.5539/jsd.v12n5p40
Accepted: August 28, $2019 \quad$ Online Published: September 29, 2019

URL: https://doi.org/10.5539/jsd.v12n5p40

\begin{abstract}
The use of winter cover crops is an important practice for the management and conservation of soil and water in southern Brazil. The objective of this work was to evaluate the accumulation of green mass and dry mass in the aerial part of winter cover crops in monocropping and intercropping in southwestern Paraná, in the years 2016 and 2017. Randomized blocks were used as experimental design with a subdivided plot scheme of $50 \mathrm{~m}^{2}$ with five replications. The cover crops used in monocropping were black oats and wheat, while for the intercropping black oats + turnips + rye + white lupin $(\mathrm{AP}+\mathrm{NF}+\mathrm{C}+\mathrm{TB})$, black oats + turnips $(\mathrm{AP}+\mathrm{NF})$ and black oats + turnips + rye + vetches + white lupin + buckwheat $(\mathrm{AP}+\mathrm{NF}+\mathrm{C}+\mathrm{E}+\mathrm{TB}+\mathrm{TM})$ were used. The data were subjected to analysis of variance and the means were compared by the Tukey test at $5 \%$ probability. The intercrop composed of black oats + turnips + rye + vetches + white lupin + buckwheat had a higher production of green mass, with an average value of $50.880 \mathrm{~kg} \mathrm{ha}^{-1}$. For the production of dry mass, the monocrop of black oats had higher yields, with an average value of $5.168 \mathrm{~kg} \mathrm{ha}^{-1}$. The highest yields were obtained in the coverage area with black oats, turnips, rye, vetches, white lupin and buckwheat, presenting a yield in 2017 of $4.487 \mathrm{~kg} \mathrm{ha}^{-1}$.
\end{abstract}

Keywords: winter cover crops, green mass, dry mass, intercrop, conservative agriculture

\section{Introduction}

Cover crops are plants that have the purpose of protecting the soil against erosion and the leaching of nutrients. Their use is widespread since the introduction and consolidation of no-tillage systems (NTS). In addition to protecting the surface of the soil, these plants improve the physical, chemical and biological properties of the soil (Derpsch et al., 1985; Giacomini et al., 2000; Pérez-Bermúdez et al., 2016; Rosseto et al., 2017).

According to Calegari and Donizeti, (2014), in the south of Brazil the use of winter cover crops is facilitated by the climatic conditions, the cultivation systems and also by the fact that during this period of the year, less area is occupied by crops of economic interest. The authors further state that cover crops can be grown alone or by intercropping with several species, with the use of intercropping being recommended as a solution because of the benefits of growing several plants at the same time.

Compared to monocropping, the intercropping of plant species promotes the formation of a soil coverage that is closer to the ideal regarding the quantity and the quality of the residues, which will bring benefits to the following crops and the NTS (Calegari \& Donizetti, 2014; Pierri et al., 2016).

Lima Filho et al. (2014) also emphasize that cover crops using the monocropping or intercropping system can 
absorb nutrients in the deep layers of soil and accumulate them in the roots or in the aerial part; when these are deposited on the soil surface, they can release part of the nutrients contained in the tissue, altering the nutrient content in the most superficial layers along the cycle of the next crop.

Some of the most used winter cover crops in the south of Brazil include grasses, crucifers and legumes. The grasses produce large amounts of dry mass and have a high carbon/nitrogen ratio, which increases the persistence of their residues on the soil's surface. The crucifers have rapid growth and promote rapid soil cover (Okello et al., 2013). The legumes are important to fix atmospheric nitrogen in association with nitrogen-fixing bacteria, speeding up the contribution of this element in the system because of the faster decomposition of their residues when it is fragmented and deposited on the soil surface (Lima Filho et al., 2014).

It is noteworthy that when planning which plants to use as soil cover, it is of fundamental importance to know the species to be used, the history of the area under cultivation, the soil and climate conditions, the production system and the proposed objectives (Penha et al., 2017).

Souza and Guimarães (2014) mention that the biomass production of the species used as cover is a result of the edaphic, climatic and phytosanitary conditions, and especially of the in-depth root development, with these factors being important for the correct establishment of winter cover crops.

As such, it should be stressed that the biomass production by the winter cover crops used in the crop rotation systems is important for the maintenance and improvement of the physical, chemical and biological balance of the soil and it may be the best indicator for the production sector for the choice of the best alternatives as a function of the climatic conditions.

In this sense, the objective of this work was to evaluate the production of green mass and dry mass by different winter cover crops in monocrop and intercrop systems as well as the yields of the soybean crop cultivated in succession to the winter crops in an area located in the southwestern region of Paraná - Brazil.

\section{Materials and Methods}

The tria was conducted in the agricultural years of 2016 and 2017 in an experimental area located in the municipality of São Jorge do Oeste - Paraná, Brazil. The area is located at latitude $25^{\circ} 44^{\prime}$ South, longitude $52^{\circ} 53^{\prime}$ West, 461 meters above sea level. According to the Köppen classification, the local climate is characterized as $\mathrm{Cfa}$, a humid subtropical mesothermic climate with hot summers, rare spells of frost, an average temperature in the coldest month below $18^{\circ} \mathrm{C}$ and an average temperature in the warmest month above $22^{\circ} \mathrm{C}$. The soil of the experiment location was described as an eutroferric red latosol (Santos et al., 2013; Embrapa, 2019) and Ferralsols/ Oxisols, (WRB/FAO, 2019). Table 1 shows the chemical characteristics of the soil of the experimental area at a depth of $0.00-0.20 \mathrm{~m}$.

Table 1. Chemical characterization of the soil in the layer of $0.00-0.20 \mathrm{~m}$

\begin{tabular}{clcccccccc}
\hline $\begin{array}{c}\mathrm{pH} \\
\mathrm{CaCl}_{2}\end{array}$ & $\mathrm{M} . \mathrm{O}$ & $\begin{array}{c}\mathrm{P} \\
(\mathrm{Resin})\end{array}$ & $\mathrm{K}$ & $\mathrm{Ca}$ & $\mathrm{Mg}$ & $\mathrm{H}+\mathrm{Al}$ & $\mathrm{SB}$ & $\mathrm{CTC}$ & $\mathrm{V}$ \\
\hline-- & $\mathrm{g} \mathrm{dm}^{-3}$ & $\mathrm{mg} \mathrm{dm}{ }^{-3}$ & & & & & & & \\
\hline 5.0 & 28.4 & 4.6 & 0.5 & 5.60 & 2.20 & 3.6 & 8.3 & 11.90 & 69.70 \\
\hline
\end{tabular}

Randomized blocks were used as experimental design with a subdivided plot scheme of $50 \mathrm{~m}^{2}$ with five replications. The cover crops used and their respective seeding densities are described in Table 2.

The experiment was conducted in an area used for the cultivation of soybean (Glycine max L.) during the summer. Before the planting and management of the cover plants, a chemical control of weeds was carried out through the application of the glyphosate herbicide $\left(1.5 \mathrm{~L} \mathrm{ha}^{-1}\right.$ of the commercial product $)$ in the project area. The cover crops were sown at the beginning of the month of May in the years of 2016 and 2017; they were evenly distributed with the aid of a manual seed distributor and incorporated into the soil with the aid of a lightweight and closed leveling rack. 
Table 2. Winter cover crops used and seeding density

\begin{tabular}{lc}
\hline Cover crops & Seeding density $\left(\mathrm{kg} \mathrm{ha}^{-1}\right)$ \\
\hline $\mathrm{AP}$ & 60 \\
$\mathrm{AP}+\mathrm{NF}+\mathrm{C}+\mathrm{TB}$ & $40+6+15+20$ \\
$\mathrm{AP}+\mathrm{NF}$ & $40+6$ \\
$\mathrm{AP}+\mathrm{NF}+\mathrm{C}+\mathrm{E}+\mathrm{TB}+\mathrm{TM}$ & $40+6+15+15+20+40$ \\
$\mathrm{TM}$ & 120 \\
\hline
\end{tabular}

AP: black oats. $\mathrm{AP}+\mathrm{NF}+\mathrm{C}+\mathrm{TB}$ : intercropping between black oats, turnips, rye and white lupin. $\mathrm{AP}+\mathrm{NF}$ : black oats + turnips. $\mathrm{AP}+\mathrm{NF}+\mathrm{C}+\mathrm{E}+\mathrm{TB}+\mathrm{TM}$ : black oats, turnips, rye, vetches, white lupin, buckwheat. $\mathrm{TM}$ : buckwheat.

After 120 days of plant development, samples of the aerial part of the cover plants were collected to determine green mass and dry mass. They were collected manually close to the ground with the aid of a knife to determine the green mass, in an area of $0.25 \mathrm{~m}^{2}$, after which they were weighed on a digital scale with the value obtained being extrapolated to $\mathrm{kg}$ per hectare. To determine the dry mass of the cover plants, the samples of green mass were dried in a closed circulation air oven at $65^{\circ} \mathrm{C}$ until reaching constant weight, after which they were weighed with the value obtained being extrapolated to $\mathrm{kg}$ per hectare.

The assessment of the soybean yield behavior in the areas under study was performed in the same areas in two consecutive years, the summer harvests of 2016 and 2017. To this end, the soybean crop was sown mechanically after desiccation and management of the cover plant residues, using a drill seeder with rod-type furrowing mechanism (machete) for the NTS in the same experimental design, taking advantage of the coverage with the remaining dry matter of the plants.

The sowing of the soybean crop was performed using a spacing of $0.45 \mathrm{~m}$, with 26 seeds $\mathrm{m}^{-1}$, using the cultivar Monsoy 7908 RR. $250 \mathrm{~kg} \mathrm{ha}^{-1}$ of the formulation 8-28-16 (20 kg ha of N, $70 \mathrm{~kg} \mathrm{ha}^{-1}$ of $\mathrm{P}_{2} \mathrm{O}_{5}$ and $40 \mathrm{~kg} \mathrm{ha}^{-1}$ of $\mathrm{K}_{2} \mathrm{O}$, respectively) was applied as sowing fertilization in accordance with the soil fertility evaluation and following the recommendations by Mascarenhas et al. (1997). Moments before sowing, an inoculation of the soybean seeds was carried out with Bradyrizobium japonicum peat $\left(6 \times 10^{6}\right.$ viable seed cells $\left.{ }^{-1}\right)$.

During the growth of the crop, all required phytosanitary treatments for the proper development of the soybean were carried out. As such, three applications of the insecticide $50 \mathrm{~g} \mathrm{~L}^{-1}$ Lambda-cyhalothrim were carried out at a dose of $150 \mathrm{~mL} \mathrm{ha}^{-1}$ at 30, 45 and 65 days after soybean emergence to control the soybean caterpillar (Anticarsia gemmatalis L.) and southern green stink bug (Nezara viridula L.).

The manual harvest of the soybean crop was performed for all plants contained in the 4 central lines of the experimental plots, disregarding $1 \mathrm{~m}$ at each end. To estimate the yield, the grain contained in the useful area of each plot was measured by weighing, expressed in tons per hectare, adjusted to $13 \%$ water content.

The collected data was submitted to analysis of variance with the $\mathrm{F}$ test to check the differences between the treatments. The comparison between the means was done with the Tukey test at a $5 \%$ significance level, using the statistical Assistat software, version 7.7 beta (Silva \& Azevedo, 2016).

\section{Results and Discussion}

The green mass yields of the different cover crops in the year of 2016 and 2017, as well as their means, are described in Table 3.It should be noted that for the green mass yields of the different species of winter cover crops, there was only a statistically significant difference for the yield means, with no statistically significant difference between the different years of cultivation.

Table 3 shows that the green mass yields of the intercropping plant cover composed by AP+NF+C+E+TB+TM had a higher mean value of $50.880 \mathrm{~kg} \mathrm{ha}^{-1}$, with this being the statistically superior treatment. The treatment with $\mathrm{AP}+\mathrm{NF}$ had a mean value of $42.030 \mathrm{~kg} \mathrm{ha}^{-1}$, which was the second largest mean among the treatments. The intercropping composed of $\mathrm{AP}+\mathrm{NF}+\mathrm{C}+\mathrm{TB}$ had the third highest mean with a yield of $35.562 \pm 4.650 \mathrm{~kg} \mathrm{ha}^{-1}$. 
Table 3. Green mass yield in the aerial part of different winter cover crops in the southwest of Paraná. Data regarding the means of five repetitions

\begin{tabular}{lccc}
\hline \multirow{2}{*}{ Cover crops } & \multicolumn{3}{c}{ Green mass $\left(\mathrm{kg} \mathrm{ha}^{-1}\right)$} \\
\cline { 2 - 4 } & $2016^{*}$ & $2017^{*}$ & Mean* \\
\hline $\mathrm{AP}$ & $26.920 \pm 3.211 \mathrm{Da}$ & $26.560 \pm 3.423 \mathrm{Da}$ & $26.740 \pm 3.317 \mathrm{Da}$ \\
$\mathrm{AP}+\mathrm{NF}+\mathrm{C}+\mathrm{TB}$ & $35.856 \pm 4.122 \mathrm{Ca}$ & $35.268 \pm 5.178 \mathrm{Ca}$ & $35.562 \pm 4.650 \mathrm{Ca}$ \\
$\mathrm{AP}+\mathrm{NF}$ & $42.848 \pm 3.564 \mathrm{Ba}$ & $41.212 \pm 3.876 \mathrm{Ba}$ & $42.030 \pm 3.720 \mathrm{Ba}$ \\
$\mathrm{AP}+\mathrm{NF}+\mathrm{C}+\mathrm{E}+\mathrm{TB}+\mathrm{TM}$ & $50.488 \pm 5.312 \mathrm{Aa}$ & $51.272 \pm 4.867 \mathrm{Aa}$ & $50.880 \pm 5.089 \mathrm{Aa}$ \\
$\mathrm{TM}$ & $27.736 \pm 2.189 \mathrm{Da}$ & $25.344 \pm 1.895 \mathrm{Da}$ & $26.540 \pm 2.042 \mathrm{Da}$ \\
\hline AP $:$ ra
\end{tabular}

AP: black oats. $\mathrm{AP}+\mathrm{NF}+\mathrm{C}+\mathrm{TB}$ : intercropping between black oats, turnips, rye and white lupin. $\mathrm{AP}+\mathrm{NF}$ : black oats + turnips. $\mathrm{AP}+\mathrm{NF}+\mathrm{C}+\mathrm{E}+\mathrm{TB}+\mathrm{TM}$ : black oats, turnips, rye, vetches, white lupin, buckwheat. $\mathrm{TM}$ : buckwheat.

*Means followed by the same uppercase letter in the row and lowercase letter in the column do not differ significantly by the Tukey test at a probability of $5 \%$.

The treatments formed by the monocrops of black oats and wheat had green mass yield values of $26.740 \pm 3.317$ $\mathrm{kg} \mathrm{ha}^{-1}$ and $26.540 \pm 2.042 \mathrm{~kg} \mathrm{ha}^{-1}$ respectively, with their means being statistically equal among themselves, but statistically lower than the other treatments.

Balbinot et al. (2004), in a study carried out in Canoinhas - SC on winter cover crops with black oats, perennial ryegrass, rye, turnips, common vetch, in mono- and intercropped crops, observed that the intercropped cover crops had higher values of green mass than the monocrops. These data are similar to those found in this study.

Vieira (1999) emphasizes that intercropping systems between species with different architectures and distinct growth patterns of the root system improve the use of environmental resources, providing greater accumulation of mass per area at a given time.

The data regarding the yields of dry mass of the different winter cover crops are presented in Table 4, with the values obtained during the years of 2016 and 2017 and the mean yield for this period. For the dry mass yields of the different species of winter cover crops, there was a statistically significant difference only for the yield means, with no statistically significant difference between the different years of cultivation.

Table 4. Dry mass yield in the aerial part of different winter cover crops in the southwest of Paraná. Data regarding the five repetitions

\begin{tabular}{llll}
\hline \multirow{2}{*}{ Cover crops } & \multicolumn{3}{c}{ Dry mass $\left({\left.\mathrm{kg} \cdot h \mathrm{ha}^{-1}\right)}\right.$} \\
\cline { 2 - 4 } & \multicolumn{1}{c}{$2016^{*}$} & \multicolumn{1}{c}{$2017^{*}$} & \multicolumn{1}{c}{ Mean* } \\
\hline $\mathrm{AP}$ & $5.160 \pm 545 \mathrm{Aa}$ & $5.176 \pm 238 \mathrm{Aa}$ & $5.168 \pm 291 \mathrm{Aa}$ \\
$\mathrm{AP}+\mathrm{NF}+\mathrm{C}+\mathrm{TB}$ & $3.784 \pm 267 \mathrm{Ba}$ & $3.692 \pm 276 \mathrm{Ba}$ & $3.738 \pm 271 \mathrm{Ba}$ \\
$\mathrm{AP}+\mathrm{NF}$ & $3.040 \pm 356 \mathrm{BCa}$ & $3.132 \pm 472 \mathrm{BCa}$ & $3.086 \pm 414 \mathrm{BCa}$ \\
$\mathrm{AP}+\mathrm{NF}+\mathrm{C}+\mathrm{E}+\mathrm{TB}+\mathrm{TM}$ & $2.952 \pm 179 \mathrm{Ca}$ & $2.984 \pm 211 \mathrm{Ca}$ & $2.968 \pm 195 \mathrm{Ca}$ \\
$\mathrm{TM}$ & $3.176 \pm 412 \mathrm{BCa}$ & $3.084 \pm 254 \mathrm{BCa}$ & $3.130 \pm 222 \mathrm{BCa}$ \\
\hline
\end{tabular}

*Means followed by the same uppercase letter in the row and lowercase letter in the column do not differ significantly by the Tukey test at a probability of $5 \%$.

AP: black oats. $\mathrm{AP}+\mathrm{NF}+\mathrm{C}+\mathrm{TB}$ : intercropping between black oats, turnips, rye and white lupin. AP+NF: black oats + turnips. $\mathrm{AP}+\mathrm{NF}+\mathrm{C}+\mathrm{E}+\mathrm{TB}+\mathrm{TM}$ : black oats, turnips, rye, vetches, white lupin, buckwheat. TM: buckwheat.

According to Table 4, the treatment containing black oats had a higher mean yield of dry mass, with the value of $5.168 \pm 291 \mathrm{~kg} \mathrm{ha}^{-1}$, which was statistically superior to the others. The treatment containing $\mathrm{AP}+\mathrm{NF}+\mathrm{C}+\mathrm{TB}$ had a dry mass yield of $3.738 \pm 271 \mathrm{~kg} \mathrm{ha}^{-1}$, which was the second highest mean among the treatments. 
The treatments containing $\mathrm{AP}+\mathrm{NF}$ and wheat, on the other hand, had dry mass yields corresponding to $3.086 \pm 414 \mathrm{~kg} \mathrm{ha}^{-1}$ and $3.130 \pm 222 \mathrm{~kg} \mathrm{ha}^{-1}$ respectively, which were statistically equal to the treatment with $\mathrm{AP}+\mathrm{NF}+\mathrm{C}+\mathrm{TB}$, which had the second best mean and also statistically equal to the treatment containing $\mathrm{AP}+\mathrm{NF}+\mathrm{C}+\mathrm{E}+\mathrm{TB}+\mathrm{TM}$, which had the lowest mean dry mass yield, with a value of $2.968 \pm 195 \mathrm{~kg} \mathrm{ha}^{-1}$.

Ziech et al. (2015), in a study conducted in the municipality of Dois Vizinhos - PR, found dry mass yield values in the monocrop cultivation of black oats and intercropping of black oats + vetches + turnips corresponding to $4.073 \mathrm{~kg} \mathrm{ha}^{-1}$ and $2.600 \mathrm{~kg} \mathrm{ha}^{-1}$, similar results to those found in this study.

In studies carried out by Giacomini et al. (2003) and Doneda, (2010) the intercropping of black oats + vetches resulted in dry mass yields equivalent to that of the monocrop oats, but higher than the result of monocrop vetches. Ceretta et al. (2002), however, observed that the cultivation of vetches intercropped with oats didn't generate increases in dry mass yields when compared to monocrops. However, according to these authors, the intercropping increased the contribution of nitrogen in the soil.

It is should be noted that phytomass yield variations for the species of coverage are common, since this characteristic is dependent on the edaphic, climatic and phytosanitary conditions (Wolschick, 2014).

Table 5 presents the data on soybean yields in the cultivation areas obtained for the years 2016 and 2017.

Table 5. Data concerning the soybean yields in the years 2016 and 2017

\begin{tabular}{lccc}
\hline \multirow{2}{*}{ Cover crops } & \multicolumn{3}{c}{ Soybean yield $\left(\mathrm{kg} \cdot \mathrm{ha}^{-1}\right)$} \\
\cline { 2 - 4 } & 2016 & 2017 & Mean \\
\hline $\mathrm{AP}$ & $3.669 \pm 213 \mathrm{Ab}$ & $4.239 \pm 346 \mathrm{Aa}$ & $3.954 \pm 279 \mathrm{~A}$ \\
$\mathrm{AP}+\mathrm{NF}+\mathrm{C}+\mathrm{TB}$ & $3.668 \pm 321 \mathrm{Ab}$ & $4.287 \pm 452 \mathrm{Aa}$ & $3.977 \pm 386 \mathrm{~A}$ \\
$\mathrm{AP}+\mathrm{NF}$ & $3.619 \pm 145 \mathrm{Aa}$ & $3.919 \pm 521 \mathrm{Aa}$ & $3.769 \pm 333 \mathrm{~B}$ \\
$\mathrm{AP}+\mathrm{NF}+\mathrm{C}+\mathrm{E}+\mathrm{TB}+\mathrm{TM}$ & $3.768 \pm 278 \mathrm{Ab}$ & $4.487 \pm 374 \mathrm{Aa}$ & $4.127 \pm 326 \mathrm{~A}$ \\
$\mathrm{TM}$ & $3.410 \pm 543 \mathrm{Bb}$ & $4.101 \pm 451 \mathrm{Aa}$ & $3.755 \pm 497 \mathrm{~B}$ \\
\hline
\end{tabular}

*Means followed by the same uppercase letter in the row and lowercase letter in the column do not differ significantly by the Tukey test at a probability of $5 \%$.

AP: black oats. $\mathrm{AP}+\mathrm{NF}+\mathrm{C}+\mathrm{TB}$ : intercropping between black oats, turnips, rye and white lupin. $\mathrm{AP}+\mathrm{NF}$ : black oats + turnips. $\mathrm{AP}+\mathrm{NF}+\mathrm{C}+\mathrm{E}+\mathrm{TB}+\mathrm{TM}$ : black oats, turnips, rye, vetches, white lupin, buckwheat. TM: buckwheat.

When analyzing the data in Table 5, one can see that there are significant differences at the $5 \%$ level of significance regarding the soybean yields obtained in the years 2016 and 2017. In the area covered with black oats (AP), the productivity in 2016 was $3.669 \pm 213 \mathrm{~kg} \mathrm{ha}^{-1}$, but in 2017 the same area yielded $4.239 \pm 346 \mathrm{~kg} \mathrm{ha}^{-1}$. The other areas showed this same behavior, with the exception of the area with black oats plus turnips (AP $+\mathrm{NF}$ ), where there was no significant difference at a $5 \%$ level of significance between the two periods under study, since $3.619 \pm 145 \mathrm{~kg} \mathrm{ha}^{-1}$ was produced in 2016, which is similar to the yield of 2017: $3.919 \pm 521 \mathrm{~kg} \mathrm{ha}^{-1}$.

The largest yields in the years of 2016 and 2017 were obtained in the area with plant covers containing black oats, turnips, rye, vetches, white lupin and buckwheat ( $\mathrm{AP}+\mathrm{NF}+\mathrm{C}+\mathrm{E}+\mathrm{TB}+\mathrm{TM})$, with yields of $3.768 \pm 278$ and $4.487 \pm 374 \mathrm{~kg} \mathrm{ha}^{-1}$. One can see that these yields differ at the level of $5 \%$ of significance.

These data show that there was an increase of about $19.1 \%$ in yields. The values obtainedare significant because they represents a productivity increase of $719 \mathrm{~kg} \mathrm{ha}^{-1}$ compared to 2016 . This also reveals that the best winter plant cover intercropping should be done with black oats, turnips, rye, vetches, white lupin and buckwheat.

In possession of the data that reported the production components of the plant, similar soybean grain production yields between the areas under study were already expected. In the evaluation of the productive components and yields when deployed in a no-tillage system under different vegetation covers (Muraishi et al., 2005; Souza \& Guimarães, 2013).

With the increased soybean yields in the areas under study, it is suggested that the increase of organic matter, released to the soil through green manuring, favors its aggregation, maintaining a stable and suitable structure for a good development of the crops (Cunha et al., 2011). Kitamura et al. (2008) tested different cover crops on 
Cerrado soil and obtained results that corroborated the improvements in the chemical, physical and biological properties (macrofauna) of the soil after the use of these plants.

In a similar study, Nicoloso et al. (2008) attributed the higher soybean yields in relation to the control to the greater soil coverage with black oats and turnip cover crops in an intercropping system, which corroborates the findings in this study. Debiasi et al. (2010), however, found no differences in soybean yields following the cover plants when compared to the fallow system.

According to Cruz Portela et al. (2010), a significant improvement in the quality of the physical soil attributes could be found with the continuous contribution of plant material to the surface, but especially through the roots of the crops and lack of soil inversion. The lower aggregation of the soil under conventional cultivation is related to a lower accumulation of organic matter on the surface (Vezzani \& Mielniczuk, 2011).

The use of cover crops, therefore, provides structural advantages that reflect on the yields of succeeding crops, ensuring the sustainability of agricultural systems over time (Llanillo et al., 2006).

\section{Conclusion}

The intercrop composed of black oats + turnips + rye + vetches + white lupin + buckwheat had a higher production of green mass.

For the dry mass, the monocrop of black oats had higher yields.

Finally, it should be noted that the grasses have a higher yield of dry mass due to their higher $\mathrm{C} / \mathrm{N}$ ratio and lower water content.

The highest soybean yields were obtained in the coverage area with black oats, turnips, rye, vetches, white lupin and buckwheat, in 2018.

\section{References}

Balbinot Junior, A. A., Backes, R., \& Tôrres, A. N. L. (2004). Desempenho de plantas invernais na produção de massa e cobertura do solo sob cultivos isolado e em consórcios. Revista de Ciências Agroveterinárias, 3, $38-42$.

Calegari, A., \& Donizeti, C. J. A. (2014). Recomendações de plantio e informações sobre o uso de espécies para adubação verde no Brasil. In: Lima Filho OF, Ambrosano EJ, Rossi F, Carlos JAD. Adubação verde e plantas de cobertura no Brasil: fundamentos e prática. Brasília, DF: Embrapa.

Ceretta, C. A., Basso, C. J., Herbes, M. G., Poletto, N., \& Silveira, M. J. (2002). Produção e decomposição de fitomassa de plantas invernais de cobertura de solo e milho, sob diferentes manejos da adubação nitrogenada. Ciencia Rural, 32(1), 49-54. https://doi.org/10.1590/S0103-84782002000100009

Cruz Portela, J., Cogo, N. P., Bagatini, T., Chagas, J. P., \& Portz, G. (2010). Restauração da estrutura do solo por sequências culturais implantadas em semeadura direta, e sua relação com a erosão hídrica em distintas condições físicas de superfície. $R$. Bras. Ci. Solo., 34, 1353-1364. https://doi.org/10.1590/S0100-06832010000400032

Cunha, E. Q., Stone, L. F., Moreira, J. A. A., Ferreira, E. P. B., Didonet, A. D., \& Leandro, W. M. (2011). Sistemas de preparo do solo e culturas de cobertura na produção orgânica de feijão e milho. $R$. Bras. Ci. Solo., 35, 589-602. https://doi.org/10.1590/S0100-06832011000200028

Debiasi, H., Levien, R., Trein, C. R., Conte, O., \& Kamimura, K. M. (2010). Produtividade de soja e milho após coberturas de inverno e descompactação mecânica do solo. P. Agrop. Bras., 45, 603-612. https://doi.org/10.1590/S0100-204X2010000600010

Derpsch, R., Sidiras, N., \& Heinznann, F. (1985). Manejo do solo com coberturas verdes de inverno. P. Agrop. Bras., 20(7), 761-773.

Doneda, A. (2010). Plantas de cobertura de solo consorciadas e em cultivo solteiro: decomposição e fornecimento de nitrogênio ao milho. Dissertações. Santa Maria, RS, Brasil. 2010.

Embrapa - Empresa Brasileira de Pesquisas Agropecuárias. Sistema Brasileiro de Classificação de Solos. Disponível

em: https://www.embrapa.br/busca-de-publicacoes/-/publicacao/1107206/sistema-brasileiro-de-classificacao-desolos Acesso em: 25 de maio de 2019.

Giacomini, S. J., Aita, C., \& Rheinheimer, D. S. (2000). Consorciação de plantas de cobertura: I. Produção e composição da fitomassa. Santa Maria, RS. 
Giacomini, S. J., Aita, C., Vendruscolo, E. R. R. O., Cubilla, M., Nicoloso, R. S., \& Fries, M. R. (2003). Matéria seca, relação $\mathrm{C} / \mathrm{N}$ e acúmulo de nitrogênio, fósforo e potássio em misturas de plantas de cobertura de solo. R. Bras. Ci. Solo., 27(2), 325-334. https://doi.org/10.1590/S0100-06832003000200012

Kitamura, A. E., Alves, M. C., Suzuki, L. G. A. S., \& Gonzalez, A. P. (2008). Recuperação de um solo degradado com a aplicação de adubos verdes e lodo de esgoto. R. Bras. Ci. Solo., 32, 405-416. https://doi.org/10.1590/S0100-06832008000100038

Lima Filho, O. F., Ambrosano, E. J., Rossi, F., \& Carlos, J. A. D. (2014). Adubação verde e plantas de cobertura no Brasil: fundamentos e prática. Brasília, DF: Embrapa.

Llanillo, R. F., Richart, A., Filho, J. T., Guimarães, M. F., \& Ferreira, R. R. M. (2006). Evolução de propriedades físicas do solo em função dos sistemas de manejo em culturas anuais. Semina: Ci. Agr., 27, 205-220. https://doi.org/10.5433/1679-0359.2006v27n2p205

Mascarenhas, H. A. A., \& Tanaka, R. T. (1997). Soja. In Raij B., Van-Cantarella H., Quaggio J. Á., \& Furlani Â. M. C. (Eds.), Recomendações de adubação e calagem para o estado de São Paulo (pp. 202-203). Campinas: Instituto Agronômico.

Muraishi, C. T., Leal, A. J. F., \& Lazarini, E. (2005). Manejo de espécies vegetais de cobertura de solo e produtividade do milho e da soja em semeadura direta. Acta Scientiarum. Agronomy, 27(2), 199-207. https://doi.org/10.4025/actasciagron.v27i2.1903

Nicoloso, R. S., Amado, T. J. C., Schneider, S., Lanzanova, M. E., Girardello, V. C., \& Bragagnolo, J. (2008). Eficiência da escarificação mecânica e biológica na melhoria dos atributos físicos de um Latossolo muito argiloso e no incremento do rendimento de soja. $R$. Bras. Ci. Solo., 32, 1735-1742. https://doi.org/10.1590/S0100-06832008000400037

Okello, C., Pindozzi, S., Faugno, S., \& Boccia, L. (2013). Bioenergy potential of agricultural and forest residues in Uganda. Biomass and Bioenergy, 56, 515-525. https://doi.org/10.1016/j.biombioe.2013.06.003

Penha, L. A. O., Passini, T., \& Gomes, H. L. L. (2017). Consórcio de canola com aveia-preta em sistema plantio direto orgânico para produção de grãos e palha e manejo de plantas daninhas. In: Anais do VI Congresso Latino Americano de Sustentabilidade. Brasília.

Pérez-Bermúdez, P. O., Olmo, M., Gil, J., García-Ferríz, L., Olmo, C., Boluda, R., \& Gavidia, I. (2016). Cover crops and pruning in Bobal and Tempranillo vineyards have little influence on grapevine nutrition. Scientia Agricola, 73, 260-265. https://doi.org/10.1590/0103-9016-2015-0027

Pierri, L., Pauletti, V., Silva, D. A., Scheraiber, C. F., Souza, J. L. M., \& Munaro, F. C. (2016). Sazonalidade e potencial energético da biomassa residual agrícola na região dos Campos Gerais do Paraná. Rev. Ceres., 63(2), 129-137. https://doi.org/10.1590/0034-737X201663020003

Rosseto, R. E., Santos, R. F., Secco, D., \& Chang, P. (2017). Temperatura do Solo e desenvolvimento de cultivos agrícolas. Journal of Agronomic Sciences, 6, 95-103.

Santos, H. G., Almeida, J. Á., Oliveira, J. B., Lubreras, J. F., Anjos, L. H. C., Coelho, M. R., ... Oliveira, V. A. (2013). Sistema brasileiro de classificação de solos. 3. ed. Rio de Janeiro, Embrapa Solos. 353 p.

Silva, F., \& Azevedo, C. (2016). The Assistat Software Version 7.7 and its use in the analysis of experimental data. African Journal of Agricultural Research, 11(39), 3733-3740. https://doi.org/10.5897/AJAR2016.11522

Souza, J. L., \& Guimarães, G. P. (2014). Alterações químicas promovidas pelo pré-cultivo de Crotalaria juncea, associada à adubação com compostos orgânicos de diferentes níveis de nitrogênio. Revista Brasileira de Agropecuária Sustentável, 3, 1-6.

Vezzani, F. M., \& Mielniczuk, J. (2011). Agregação e estoque de carbono em Argissolo submetido a diferentes práticas de manejo agrícola. $R$. Bras. Ci. Solo., 35, 213-223. https://doi.org/10.1590/S0100-06832011000100020

Vieira, C. (1999). Estudo monográfico do consórcio milho-feijão no Brasil. Viçosa: UFV. 183p.

Wolschick, N. H. (2014). Desempenho de plantas de cobertura e influência nos atributos do solo e na produtividade de culturas em sucessão. Lages. 93 p.

WRB/FAO - Embrapa - Empresa Brasileira de Pesquisas Agropecuárias. Sistema Brasileiro de Classificação de Solos.

Disponível

em: 
https:/www.embrapa.br/busca-de-publicacoes/-/publicacao/1107206/sistema-brasileiro-de-classificacao-desolos. Acesso em: 25 de maio de 2019.

Ziech, A. R. D., Conceição, P. C., Luchese, A. V., Balin, N. M., Candiotto, G., \& Garmus, T. G. (2015). Proteção do solo por plantas de cobertura de ciclo hibernal na região Sul do Brasil. Pesquisa Agropecuária Brasileira, 50(5), 374-382. https://doi.org/10.1590/S0100-204X2015000500004

\section{Copyrights}

Copyright for this article is retained by the author(s), with first publication rights granted to the journal.

This is an open-access article distributed under the terms and conditions of the Creative Commons Attribution license (http://creativecommons.org/licenses/by/4.0/). 